\title{
Super-Fast Low Power (SFLP) SRAM Cell for Read/Write Operation
}

\author{
C.M.R. Prabhu \\ Faculty of Engineering and Technology \\ Multimedia University, Melaka \\ Malaysia
}

\author{
Ajay Kumar Singh \\ Faculty of Engineering and Technology \\ Multimedia University, Melaka \\ Malaysia
}

\begin{abstract}
In this paper a Super-Fast Low-Power (SFLP) static random access memory (SRAM) cell has been proposed. The SFLP cell contains two tail transistors in the pull-down path of the respective inverter to minimize the write power consumption The cell is simulated in terms of speed, power and read stability. The simulated results show that the read and write power of the proposed cell is reduced up to $38 \%$ and $55 \%$ at $1.2 \mathrm{~V}$ respectively and cell achieves $2.2 \mathrm{x}$ higher read static noise margin (SNM) compared to the conventional 6T SRAM cell.
\end{abstract}

\section{General Terms}

SRAM, delay, power, write margin, threshold voltage, SNM..

\section{Keywords}

Static random access memory, PD-SOI, Write power, Write/read performance, Read SNM.

\section{INTRODUCTION}

Due to requirement of light and portable devices, the demand high performance, low power digital very large scale integration (VLSI) system has increased [1-2]. In modern digital VLSI system, SRAM cell occupies a larger area on the chip. It is a great challenge to the researchers to restrict the power consumption in the modern processor due to demand of green technology. The power consumption of the systems can be reduced by reducing the power consumption of caches which occupies $60 \%$ to $70 \%$ of chip area. The power dissipated by caches is usually a major part of the total dissipated power. Due to this, design of power efficient high performance SRAM cell has gained importance. Various low power SRAM cell designs have been proposed [3-7]. Each design has its own merits and demerits. The cell stability is another important consideration for the cell designer $[8,9]$.

In the present paper, a new Super-Fast Low-Power (SFLP) SRAM cell for read/write operation is proposed. The proposed cell is similar to the novel 8T SRAM cell except one extra transistor. This extra transistor is known as read access transistor, which is used to form the separate discharging path (read access transistor plus pull down transistor) during the read operation. Due to isolated read and write circuits, the read SNM of the proposed cell is enhanced. To avoid the any instability on the storage nodes in the unselected cells of the proposed 8T SRAM array, the switching behavior of the SFLP tail transistors are controlled by the respective storage nodes. During the write operation, the SFLP SRAM cell is similar to the Ref. [7] circuit which reduces the power consumption and reduces the write access time. The read operation is performed by only one bit line whereas write operation is performed by two bit lines. Since, the discharging activity factor of the Super-Fast Low-Power (SFLP) cell is lower than the $6 \mathrm{~T}$ cell, average read power consumption is $38 \%$ lower compared to the 6T SRAM cell. All the results are simulated in a CMOS $0.12 \mu \mathrm{m}$ technology using MICROWIND3 CAD tools [10]. The rest of the paper is organized as follows. In section 2, the operation of Super-Fast Low-Power (SFLP) cell is explained. Simulated results are discussed in section 3. Section 4 concludes the paper.

\section{PROPOSED CIRCUIT DESCRIPTION}

The complete schematic of the proposed Super-Fast LowPower (SFLP) cell is shown in Fig. 1(a). The SFLP cell is divided into two circuits: write circuit and read circuit. The write circuit is similar to the 8T cell [7] and it is used to perform the write operation. The read operation is performed by two transistors (N7 and N5) which are used to perform the read operation. Transistor N7 is used to decouple the cell node from the read bit line during write operation/sleep mode. Due to this new design technique, the previously stored data remains intact in the cell during next write operation as long as RWL $=0$. The layouts of the $6 \mathrm{~T}$ and Super-Fast LowPower (SFLP) SRAM cells, as shown in Fig. 1(b), are drawn in standard $0.12 \mu \mathrm{m}$ CMOS technology. The proposed SRAM cell has an area overhead of $11.7 \%$ due to additional two tail transistors. Because, the percentage of cell array to cache area is about $70 \%$, the overall cache overhead is roughly $(11.7 \%$ $\mathrm{x} 70 \%)=8.2 \%$ due to the proposed cell. The detail operation of the SFLP SRAM cell is:

During write operation read word line (RWL) is set to low so that write circuit completely decouples from the read circuit. The write operation in the proposed cell is performed by setting the bitlines (BL and BLB) to the desired logic. During write operation, the proposed SRAM cell behaves as the 8T cell [7]. In the SFLP cell, the switching behaviors of tail transistors are controlled by the respective logic on the storage nodes $\mathrm{Q}$ and $\mathrm{nQ}$.

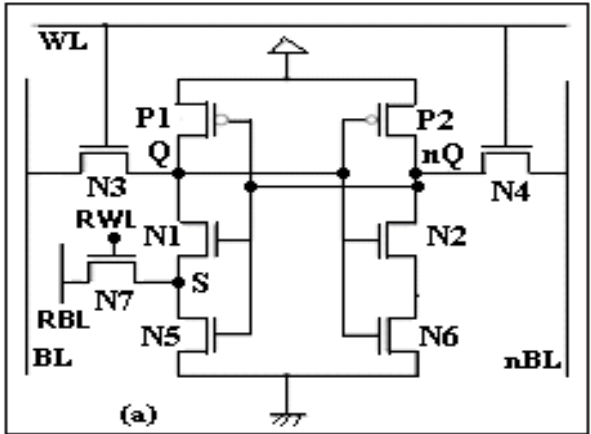

Fig 1: (a) SFLP SRAM cell 
A read operation $(\mathrm{RWL}=1, \mathrm{WL}=0)$ is performed by reading the data with help of the transistors N7 and N5. In read 1 operation, the transistor N5 is turned OFF, flips the node $\mathrm{S}$ to logic high, without allowing RBL to discharge which results lower power consumption. When node nQ stores data "1" (read 0 operation), transistor N5 turns ON. Now, the bitline (RBL) discharges through read access transistor N7 and pull down transistor N5. Since, storage nodes Q and nQ are completely isolated from bitlines during read operation; the voltage of the node which stores 0 is strictly maintained at the ground level.

\section{SIMULATION RESULTS AND DISCUSSIONS}

We have performed the simulation with help of BSIM4 model for $0.12 \mu \mathrm{m}$ process technology. Threshold voltage of nMOS (pMOS) is set to $400 \mathrm{mV}$. The 6T, Zero aware (ZA) [6], novel 9T (N.9T) [7], 8T [8], novel 8T (N.8T) [9] and SFLP cells are simulated and compared in terms of power consumption, access delay and current through each transistor. The simulated results are given in Tables (Table 1 -Table 7). In the proposed cell, overall power consumption is small compared to the $6 \mathrm{~T}$ cell and other cells for $1 \rightarrow 1 \quad / 0 \rightarrow 0$ write pattern. This is due to the no state transition and reduced sub-threshold current. Subthreshold leakage current is small (Table 7) due to the stack effect. Stacking of transistors is an effective way to reduce the subthreshold leakage current [4]. In $1 \rightarrow 0 / 0 \rightarrow 1$ write pattern, power consumption is reduced due to no discharging activity at bitline (Table 1). The power dissipated in bitlines is only a part of the total cache power consumption due to increase in height of the proposed cell. The tag bitlines contribute only about $3 \%$ to the total cache power consumption during write operation [6]. The increased power consumption in wordline of the proposed cell during write mode can be compensated by equalizing the width of SFLP cell and the 6T cell layouts. The proposed cell height is longer than the $6 \mathrm{~T}$ cell that increases the bitlines capacitace from $27.76 \mathrm{fF}$ for the $6 \mathrm{~T}$ cell to $32.51 \mathrm{fF}$ for the proposed array with 128 cells per column in $0.12 \mu \mathrm{m}$ technology. The total column write power consumption reduced by $71.31 \%$ in the SFLP cell for $0 \rightarrow 0$ and $1 \rightarrow 1$ write transitions where as $37.8 \%$ column power reduction is observed for $1 \rightarrow 0$ and $0 \rightarrow 1$ write patterns in the SFLP cell due to two tail transistors in the write circuit.

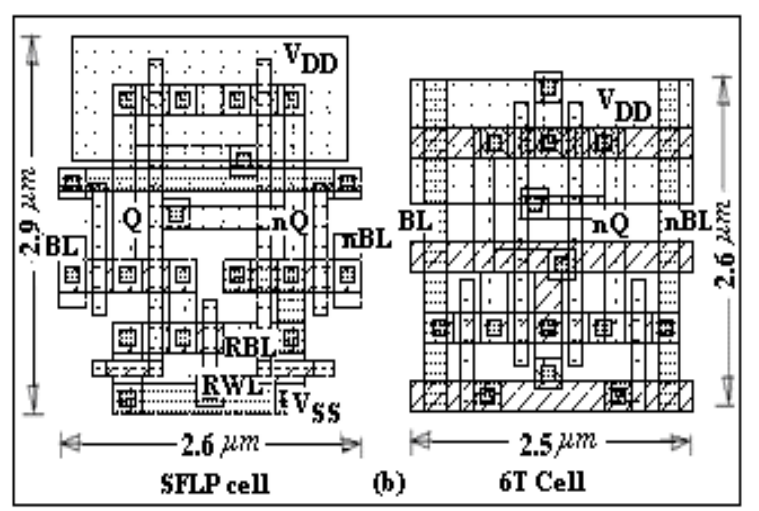

Fig 1: (b) Cell Layout
It is clear that the proposed SFLP SRAM cell consumes approximately $53.2 \%$ less average column write power (ACWP) than the conventional 6T SRAM cell. The $1 \rightarrow 0 / 0 \rightarrow 1$ write transition speed of the proposed cell is faster than the conventional 6T cell and ZA cell (Table 1(a) \&(b)), due to one OFF transistor in the pull down path of the inverter which lowers the discharging/charging time of bitlines. In the SFLP cell, a write operation can be performed for a minimum VWL value which is equal to the $0.56 \mathrm{~V}$ instead of $0.81 \mathrm{~V}$ as in the $6 \mathrm{~T}$ cell (see Table 3). This indicates larger write margin of the proposed cell.

For read " 1 " operation $(\mathrm{Q}=1 \& \mathrm{nQ}=0)$, transistor $\mathrm{N} 5$ turned OFF and flips the node $S$ to high. Due to no discharge at RBL considerable power is saved as seen in table 2. During read "0" operation, RBL discharges through two ON transistors N7 and N5. The average percentage read power reduction is $38 \%$ compared to the other cells (see Table 2). The read 1 access time is faster compared to the 6T cell (see Table 4). The read 0 delay is same compared to the conventional $6 \mathrm{~T}$ cell. Table 7 gives the current flow through various transistors used in the 6T cell, 8T cell [7] and SFLP cell during read operation. Fig. 3 gives the variation of read power consumption with temperature for the 6-T cell and other cells. The proposed cell can be used up to $\mathrm{T}=120^{\circ} \mathrm{C}$ with minimal power loss. This smaller change in power consumption is due to absence of leakage paths during read operation and due to isolation of write circuit from read circuit in SFLP cell. Due to isolation of read and write circuits, the read stability is enhanced and node $\mathrm{Q}$ is maintained strictly at $0 \mathrm{~V}$ for $\mathrm{nQ}=\mathrm{V}_{\mathrm{dd}}$ (see Fig. 3)). The read SNM of the SFLP cell $(420 \mathrm{mV})$ is approximately 2.2xhigher than the SNM of the 6-T cell $(195 \mathrm{mV})$ and 1.3xlarger than the novel $8 \mathrm{~T}$ cell [7] with a symmetrical butterfly curve. The use of low $\mathrm{V}_{\mathrm{TH}}\left(\mathrm{V}_{\mathrm{TH}}=0.3 \mathrm{~V}\right)$, transistors M7, M8 and M9 in the SFLP cell reduce the read SNM to $399 \mathrm{mV}$ compared to $110 \mathrm{mV}$ of novel 8 -T cell. The SNM at different threshold voltages is given in Table 5. Due to increased change in current in current balance $\mathrm{P} 1 / \mathrm{N} 1$ and $\mathrm{P} 2 / \mathrm{N} 2$ at high temperature $\left(\mathrm{T}=120^{\circ} \mathrm{C}\right)$, read $\mathrm{SNM}$ decreases to $380 \mathrm{mV}$ from its room temperature value (Table 6). The percentage decrease in SNM temperature increases from $27^{\circ} \mathrm{C}$ to $120^{\circ} \mathrm{C}$ is only $9.5 \%$ in SFLP SRAM cell compared to $21 \%$ in novel $8 \mathrm{~T}$ cell [7]. Fig. 2 gives the variation of read power consumption with temperature for the SFLP and the 6-T cells. The proposed cell can be used even in worse condition $\left(\mathrm{T}=120^{\circ} \mathrm{C}\right)$ with minimal power loss $(10 \%$ in SFLP cell compared to $21 \%$ in novel $8 \mathrm{~T}$ cell [7]). This smaller change in read power consumption is due to isolation of write circuit from read circuit in SFLP cell.

Table 1(a). Summary of write power for different input

\begin{tabular}{|ccccc|}
\hline & \multicolumn{4}{c|}{ WRITE POWER $(\mu \mathrm{W})$} \\
\cline { 2 - 5 } & $0 \rightarrow 0$ & $0 \rightarrow 1$ & $1 \rightarrow 0$ & $1 \rightarrow 1$ \\
\hline 6T & 0.002 & 30.699 & 30.695 & 0.002 \\
ZA [6] & 0.0025 & 31.498 & 6.646 & 0.0015 \\
N.9T[8] & 0.002 & 31.488 & 31.487 & 0.002 \\
8T[7] & 0.0005 & 18.195 & 18.191 & 0.0005 \\
N.8T[9] & 0.002 & 7.201 & 31.513 & 0.001 \\
SFLP & 0.0005 & 20.004 & 20.005 & 0.0005 \\
\hline
\end{tabular}


Table 1(b). Summary of write Delay

\begin{tabular}{|ccccc|}
\hline & \multicolumn{5}{c|}{ WRITE DELAY(ps) } \\
\cline { 2 - 5 } & $0 \rightarrow 0$ & $0 \rightarrow 1$ & $1 \rightarrow 0$ & $1 \rightarrow 1$ \\
\hline 6T & - & 111 & 111 & - \\
ZA [6] & - & 116 & 110 & - \\
N.9T[8] & & 114 & 114 & \\
8T[7] & & 60 & 60 & \\
N.8T[9] & - & 121 & 117 & - \\
SFLP & - & 62 & 62 & \\
\hline
\end{tabular}

Table 2. Average read power and area

\begin{tabular}{|lll|}
\hline $\begin{array}{l}\text { SRAM } \\
\text { cells }\end{array}$ & $\begin{array}{l}\text { Average read } \\
\text { Power } \\
\text { Consumption } \\
(\mu \mathrm{W})\end{array}$ & $\begin{array}{l}\text { Area } \\
\left(\mu \mathrm{m}^{2}\right)\end{array}$ \\
\hline $6 \mathrm{~T}$ & 28.496 & $2.6 \times 2.6$ \\
ZA[6] & 30.379 & $2.6 \times 2.9$ \\
N.9T [8] & 25.510 & $2.6 \times 3.3$ \\
8T [ 7] & 31.586 & $2.6 \times 2.9$ \\
N.8T[9] & 24.327 & $2.6 \times 3.4$ \\
SFLP & 17.754 & $2.6 \times 2.9$ \\
\hline
\end{tabular}

Table 3.Access transistor $\left(I_{\mathrm{N} 4}\right)$ current

\begin{tabular}{|llllll|}
\hline $\mathrm{V}_{\mathrm{WL}}$ & \multicolumn{3}{l}{$\mathrm{I}_{\mathrm{N} 4}$ in $\mu \mathrm{A}$} \\
\cline { 2 - 6 } (volts) & $6 \mathrm{~T}$ & $\mathrm{ZA}$ & $8 \mathrm{~T}$ & $\mathrm{LPF}$ & SFLP \\
& & {$[6]$} & {$[7]$} & {$[9]$} & \\
\hline 1.2 & 98 & 75 & 75 & 75 & 76 \\
1.0 & 98 & 74 & 73 & 73 & 74 \\
0.81 & 96 & 71 & 71 & 71 & 70 \\
0.63 & - & 61 & 60 & 60 & 61 \\
0.62 & - & 57 & 58 & 58 & 59 \\
0.60 & - & - & - & - & 58 \\
0.58 & - & - & - & - & 56 \\
\hline
\end{tabular}

Table 4. Read Delay

\begin{tabular}{|lll|}
\hline SRAM cell & \multicolumn{2}{l|}{ Read Delay (ps) } \\
\cline { 2 - 3 } & Read '0' & Read '1' \\
\hline 6T & 80 & 80 \\
ZA[6] & 81 & 90 \\
N. 9T[8] & 94 & 94 \\
8T [7] & 90 & 90 \\
N.8T[9] & 85 & 14 \\
SFLP & 80 & 14 \\
\hline
\end{tabular}

Table 5. SNM for different VTH

\begin{tabular}{|c|c|c|c|c|c|c|}
\hline \multirow[t]{3}{*}{$\mathbf{V}_{\mathrm{TH}}$} & \multicolumn{6}{|c|}{$\mathrm{SNM}(\mathrm{mV})$} \\
\hline & 6T & $\mathbf{Z A}$ & N.9T & $8 T$ & N.8T & SFLP \\
\hline & & {$[6]$} & [8] & [7] & [9] & \\
\hline 0.3 & - & 106 & 352 & 110 & 359 & 399 \\
\hline 0.4 & 195 & 155 & 390 & 165 & 397 & 420 \\
\hline 0.7 & - & 398 & 433 & 405 & 443 & 465 \\
\hline
\end{tabular}

Table 6. SNM with different Temperature

\begin{tabular}{|lllllll|}
\hline Temp & \multicolumn{2}{l}{ SNM(mV) } \\
\cline { 2 - 7 }$\left({ }^{\circ} \mathrm{C}\right)$ & $6 \mathrm{~T}$ & $\mathrm{ZA}$ & N.9T & $8 \mathrm{~T}$ & N.8T & SFLP \\
& & {$[6]$} & {$[8]$} & {$[7]$} & {$[9]$} & \\
\hline-20 & - & 167 & 409 & 236 & 400 & 442 \\
27 & 195 & 155 & 390 & 225 & 397 & 420 \\
120 & - & 130 & 445 & 177 & 331 & 380 \\
\hline
\end{tabular}


Table 7. Current through each transistor during write/read 0 operations

\begin{tabular}{|c|c|c|c|c|c|c|}
\hline & & \multicolumn{4}{|c|}{ WRITE OPERATION } & \multirow{2}{*}{$\begin{array}{c}\text { READ OPERATION } \\
\text { READ “0” }\end{array}$} \\
\hline & & ${ }_{0} \rightarrow_{0}$ & ${ }_{0} \rightarrow_{1}$ & ${ }_{1} \rightarrow_{0}$ & ${ }_{1} \rightarrow_{1}$ & \\
\hline \multirow[t]{4}{*}{$6 \mathrm{~T}$} & $\mathrm{I}_{\mathrm{N} 3}$ & $0.623 \mathrm{nA}$ & $0.051 \mathrm{~mA}$ & $0.100 \mathrm{~mA}$ & $0.623 \mathrm{nA}$ & $0.043 \mathrm{~mA}$ \\
\hline & $\mathrm{I}_{\mathrm{N} 4}$ & $0.623 \mathrm{nA}$ & $0.100 \mathrm{~mA}$ & $0.051 \mathrm{~mA}$ & $0.623 \mathrm{nA}$ & $0.312 \mathrm{nA}$ \\
\hline & $\mathrm{I}_{\mathrm{N} 1}$ & $1.623 \mathrm{nA}$ & $0.050 \mathrm{~mA}$ & $0.039 \mathrm{~mA}$ & $24.61 n A$ & $0.042 \mathrm{~mA}$ \\
\hline & $\mathrm{I}_{\mathrm{N} 2}$ & $24.61 n A$ & $0.039 \mathrm{~mA}$ & $0.050 \mathrm{~mA}$ & $1.623 \mathrm{nA}$ & $0.312 \mathrm{nA}$ \\
\hline \multirow[t]{7}{*}{ N.9T[8] } & $\mathrm{I}_{\mathrm{N} 3}$ & $0.623 \mathrm{nA}$ & $0.055 \mathrm{~mA}$ & $0.110 \mathrm{~mA}$ & $0.623 \mathrm{nA}$ & $0.045 \mathrm{~mA}$ \\
\hline & $\mathrm{I}_{\mathrm{N} 4}$ & $0.623 \mathrm{nA}$ & $0.110 \mathrm{~mA}$ & $0.055 \mathrm{~mA}$ & $0.623 \mathrm{nA}$ & $0.330 \mathrm{nA}$ \\
\hline & $\mathrm{I}_{\mathrm{N} 1}$ & $1.623 \mathrm{nA}$ & $0.052 \mathrm{~mA}$ & $0.041 \mathrm{~mA}$ & $24.61 \mathrm{nA}$ & $0.043 \mathrm{~mA}$ \\
\hline & $\mathrm{I}_{\mathrm{N} 2}$ & $24.61 \mathrm{nA}$ & $0.041 \mathrm{~mA}$ & $0.052 \mathrm{~mA}$ & $1.623 \mathrm{nA}$ & $0.330 \mathrm{nA}$ \\
\hline & $\mathrm{I}_{\mathrm{N} 5}$ & - & - & - & - & $0.013 \mathrm{~mA}$ \\
\hline & $\mathrm{I}_{\mathrm{N} 6}$ & - & - & - & - & $0.001 \mathrm{~mA}$ \\
\hline & $\mathrm{I}_{\mathrm{N} 7}$ & - & - & - & - & $0.014 \mathrm{~mA}$ \\
\hline \multirow[t]{6}{*}{$8 \mathrm{~T}[7]$} & $\mathrm{I}_{\mathrm{N} 3}$ & $0.312 \mathrm{nA}$ & $0.001 \mathrm{~mA}$ & $0.075 \mathrm{~mA}$ & $0.312 \mathrm{nA}$ & $0.046 \mathrm{~mA}$ \\
\hline & $\mathrm{I}_{\mathrm{N} 4}$ & $0.312 \mathrm{nA}$ & $0.075 \mathrm{~mA}$ & $0.001 \mathrm{~mA}$ & $0.312 \mathrm{nA}$ & $0.312 \mathrm{nA}$ \\
\hline & $\mathrm{I}_{\mathrm{N} 5}$ & $0.312 \mathrm{nA}$ & $0.312 \mathrm{nA}$ & $0.034 \mathrm{~mA}$ & $3.425 \mathrm{nA}$ & $0.045 \mathrm{~mA}$ \\
\hline & $\mathrm{I}_{\mathrm{N} 6}$ & $3.425 \mathrm{nA}$ & $0.034 \mathrm{~mA}$ & $0.312 \mathrm{nA}$ & $0.312 \mathrm{nA}$ & $0.312 \mathrm{nA}$ \\
\hline & $\mathrm{I}_{\mathrm{N} 1}$ & $0.312 \mathrm{nA}$ & $0.312 \mathrm{nA}$ & $0.034 \mathrm{~mA}$ & $3.425 \mathrm{nA}$ & $0.045 \mathrm{~mA}$ \\
\hline & $\mathrm{I}_{\mathrm{N} 2}$ & $0.312 \mathrm{nA}$ & $0.034 \mathrm{~mA}$ & $0.312 \mathrm{nA}$ & $0.312 \mathrm{nA}$ & $0.312 \mathrm{nA}$ \\
\hline \multirow[t]{7}{*}{ N.8T[9] } & $\mathrm{I}_{\mathrm{N} 3}$ & - & - & - & - & - \\
\hline & $\mathrm{I}_{\mathrm{N} 4}$ & $0.623 \mathrm{nA}$ & $0.075 \mathrm{~mA}$ & $0.051 \mathrm{~mA}$ & $0.312 \mathrm{nA}$ & $0.312 \mathrm{nA}$ \\
\hline & $\mathrm{I}_{\mathrm{N} 1}$ & $1.623 \mathrm{nA}$ & $0.312 \mathrm{nA}$ & $0.039 \mathrm{~mA}$ & $3.425 \mathrm{nA}$ & $0.045 \mathrm{~mA}$ \\
\hline & $\mathrm{I}_{\mathrm{N} 2}$ & $24.61 \mathrm{nA}$ & $0.034 \mathrm{~mA}$ & $0.050 \mathrm{~mA}$ & $0.312 \mathrm{nA}$ & $0.312 \mathrm{nA}$ \\
\hline & $\mathrm{I}_{\mathrm{N} 5}$ & - & - & - & - & $0.013 \mathrm{~mA}$ \\
\hline & $\mathrm{I}_{\mathrm{N} 6}$ & - & - & - & - & $0.001 \mathrm{~mA}$ \\
\hline & $\mathrm{I}_{\mathrm{N} 7}$ & - & - & - & - & $0.014 \mathrm{~mA}$ \\
\hline \multirow[t]{7}{*}{ SFLP } & $\mathrm{I}_{\mathrm{N} 3}$ & $0.312 \mathrm{nA}$ & $0.003 \mathrm{~mA}$ & $0.076 \mathrm{~mA}$ & $0.312 \mathrm{nA}$ & $0.312 \mathrm{nA}$ \\
\hline & $\mathrm{I}_{\mathrm{N} 4}$ & $0.312 \mathrm{nA}$ & $0.076 \mathrm{~mA}$ & $0.003 \mathrm{~mA}$ & $0.312 \mathrm{nA}$ & $0.518 \mathrm{nA}$ \\
\hline & $\mathrm{I}_{\mathrm{N} 5}$ & $0.312 \mathrm{nA}$ & $0.312 \mathrm{nA}$ & $0.034 \mathrm{~mA}$ & $0.312 \mathrm{nA}$ & $0.002 \mathrm{~mA}$ \\
\hline & $\mathrm{I}_{\mathrm{N} 6}$ & $3.425 \mathrm{nA}$ & $0.034 \mathrm{~mA}$ & $0.312 \mathrm{nA}$ & $3.425 \mathrm{nA}$ & $0.312 \mathrm{nA}$ \\
\hline & $\mathrm{I}_{\mathrm{N} 1}$ & $0.312 \mathrm{nA}$ & $0.312 \mathrm{nA}$ & $0.034 \mathrm{~mA}$ & $0.312 \mathrm{nA}$ & $0.001 \mathrm{nA}$ \\
\hline & $\mathrm{I}_{\mathrm{N} 2}$ & $0.312 \mathrm{nA}$ & $0.034 \mathrm{~mA}$ & $0.312 \mathrm{nA}$ & $0.312 \mathrm{nA}$ & $0.518 \mathrm{nA}$ \\
\hline & $\mathrm{I}_{\mathrm{N} 7}$ & - & - & - & - & $0.003 \mathrm{~mA}$ \\
\hline
\end{tabular}




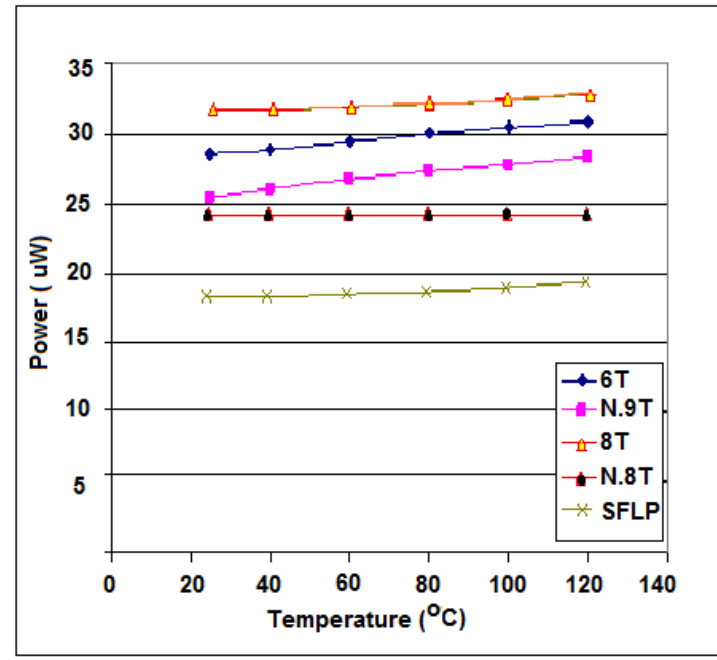

Fig. 2. Read Power with temperature

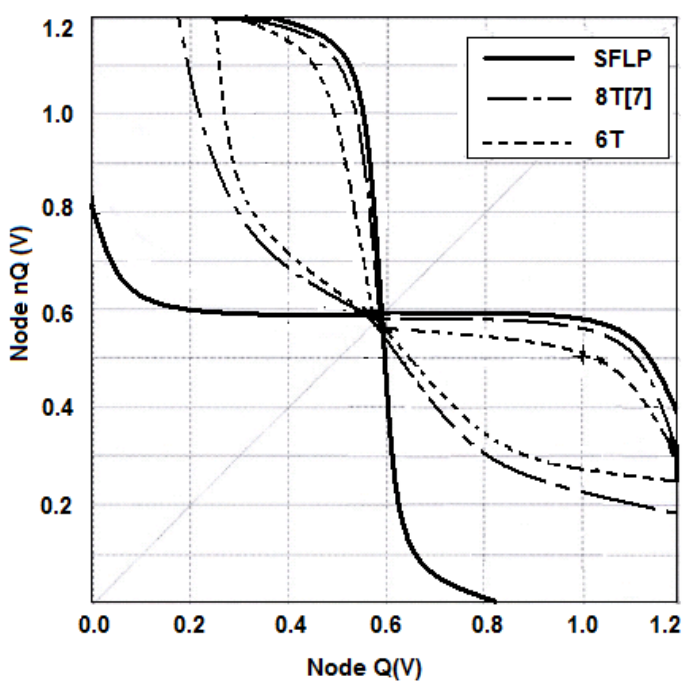

Fig. 3.Graphical representation of SNM

\section{CONCLUSION}

In the proposed cell, the power saves up to $55 \%$ during write operation and 38\% during read operation compared to the $6 \mathrm{~T}$ cell. The average column write power reduces in the SFLP SRAM cell. The SNM of the proposed SFLP cell is $2.2 \mathrm{x}$ higher than the 6-T cell and $1.3 \mathrm{x}$ the novel $8 \mathrm{~T}$ cell. The SFLP cell and be used in worse condition $\left(\mathrm{T}=120^{\circ} \mathrm{C}\right)$ with minimal power loss and stability loss.

\section{REFERENCES}

[1] N.S. Kim, D. Blaauw, T. Mudge, "Quantitative analysis and opti- mization techniques for on-chip cache leakage power," IEEE Trans. Very Large Scale Integr. (VLSI) Syst., vol. 13, no. 10, pp. 1147-1156, Oct. 2005.

[2] M. Yamaoka, R. Tsuchiya, and T. Kawahara, "SRAM circuit with ex- panded operating margin and reduced stand-by leakage current using ThinBOX FD-SOI transistors," IEEE J. Solid-State Circuits, vol. 41, no. 11, pp. 2366-2372, Nov. 2006.

[3] S. Inaba, H. Nagano, K. Miyano, I. Mizuushima, Y. Okayama, T. Nakauchi, K. Ishimaru, and H. Ishiuchi, " Low-power logic circuit and SRAM cell applications with silicon on depletion layer CMOS (SODEL CMOS) technology," IEEE J.

Solid-State Circuits, vol. 41, no. 6,

pp. 1455-1462, June 2006

[4] A. Chandrakasan, W. J. Bowbill and F. Fox, "Design of High Performance Microprocessor Circuits," Wiley-IEEE Press, p. 584, 2000.

[5] E. Grossar, M. Stucchi, K. Maex, and W. Dehaene, "Read stability and write-ability analysis of SRAM cells for nanometer technologies," IEEE Solid-State Circuits, vol. 41, no. 11, pp. 2577-2588, Nov. 2006.

[6] Y. Chang, F. Lai, and C. Yang, "Zero-aware asymmetric SRAM cell for reducing cache power in writing zero," IEEE Trans. Very Large Scale Integr (VLSI) Syst., vol. 12, no. 8, pp. 827-836, Aug. 2004.

[7] C.M.R. Prabhu and A.K. Singh, Novel Eight-Transistor SRAM cell for Write Power reduction," IEICE Electron. Express, vol.7, no. 16, pp. 1175-1181, 2010.

[8] Z. Liu and V. Kursun, "Characterization of a Novel Nine-Transistor SRAM cell," IEEE Trans. Very Large Scale Integr. (VLSI) Syst., vol. 16, no. 4, pp. 488-492, Aug. 2008.

[9] A. Sil, S. Ghosh, and M. Bayoumi, "A Novel 8T SRAM Cell with improved Read-SNM," Circuits and Systems, 2007, NEWCAS 2007. IEEE Northeast Workshop, vol. 5-8, pp 1289-1292, Aug. 2007.

[10] E. Sicard, "Microwind and Dsch version 3.0," Published by INSA Toulouse France, April 2005. [online] Available: http://www.microwind.org. 